\title{
FrontLine RESPONSE TO High IMPACT DOMESTIC VIOLENCE IN HUNGARY
}

\author{
GÁBOr HÉRA \& DÓRA SZEGŐ
}

Foresee Research Group, Budapest, Hungary.

E-mail: gabor.hera@foresee.hu; szegodori@gmail.com

Abstract The first part of the chapter describes the legalisation of domestic violence. The Criminal Code criminalises domestic violence, including several areas of domestic violence such as emotional, physical, economic, and sexual violence. Two main limitations are that the Criminal Code does not sanction verbal abuse, and the police are obliged to file a criminal complaint ex officio only if domestic violence involves serious physical injuries. In all other cases, it is upon the request of the victim to file a criminal complaint against the offender. The second part of the chapter describes the roles of the different front-line agencies in responding to domestic violence; the police, the Child Protection Perceiving and Reporting System, the Guardianship office, the family support and child welfare services and the different NGO's that operate crisis management and different helplines. The next part of the chapter introduces the work of the National Crisis Telephone Helpline as a good practice of cooperation between stakeholders that helps victims of domestic violence and human trafficking through a free of charge telephone line. The last part shows the main challenges and shortcomings characterising the handling of domestic violence in Hungary.

Keywords:

domestic violence, Hungary, interagency cooperation, victims, police, NGO 


\section{Short description of Hungary's history and legislation regarding domestic violence}

In Hungary, several legislative and policy-related steps took place before domestic violence as a crime became part of the Criminal Code (Act C of 2012 on the Criminal Code), passed only in 2012. Among its antecedents, the most important ones were the following: the first law, which directly regulated issues related to domestic violence, was Act XXXI of 1997 on the protection of children and administration of guardianship. That law aimed at ratifying the children's fundamental rights as defined by the United Nations Convention on the Rights of the Child. The law described violent acts within families that are directed against children. It should also be mentioned that, since the amendment of the Criminal Code in 1997, forced intercourse and acts of indecency between spouses were subject to punishment.

The government has established the National Strategy for Social Crime Prevention in 2003 (Parliamentary Decree No: 115/2003 (X.28.) on the National Strategy for Social Crime Prevention), which covered the issue of domestic violence as a priority area. In line with the National Strategy, an instruction of the Hungarian National Police Headquarters was passed in 2003 that addressed domestic violence (hereinafter: DV) and victims thereof more precisely (Hungarian National Police Instruction (III. 27) No: 13/2003 on the tasks of the police force related to domestic violence and the defence of minors). A new police instruction was passed in 2007 (Hungarian National Police Instruction (OT 26.) No: 32/2007 on the execution of police tasks related to handling violence between family members and the protection of minors), which replaced the previous one and regulated tasks of the police handling violence between family members and the protection of minors. The instruction referred to various criminal acts of the Criminal Code that in special instances are considered violent domestic crimes. Victims of DV are "all those who are the direct victims of the DV offences, as well as those, who suffered physical, mental, emotional or moral harm in relation to the offences, including those relatives, who were not directly targeted by the violence" - as defined by the above mentioned document (OT 26.; No: 32/2007). 
The next, significant legislative step was the establishment of the legal framework of restraining orders (Act LXXII of 2009 on restraining orders applicable due to violence between family members). A temporary preventive restraining order is ordered by the police, prohibiting any contact by the offender towards the victim for 72 hours, in order to prevent further, serious harm. Preventive restraining orders can be requested by the police, by the victim, or by the victim's representative before the court and ordered by the court for a maximum of 60 days. (ibid, Article 14 (1)).

In addition to this, the court of justice is obliged to report any threat of violence between family members and endangerment of children (ibid, Article 2 (1)). Such reports shall be made to the guardianship office, to the child welfare services, and if there are circumstances detected that make temporary preventive restraining reasonable in a civil lawsuit, the court of justice shall also report this to the police (ibid, Article 17 (1)).

There is a further form of a restraining order, not exclusively targeting domestic violence cases. Contrary to the temporary preventive restraining orders, it is always ordered as part of a criminal procedure, initiated against the defendant by the investigative authority, ordered by the judge in case of a significant risk of committing violent crimes. Based on a personal hearing, the necessary measures shall be taken to prevent and stop violence between family members.

The Criminal Code (Act C of 2012 on the Criminal Code) includes provisions regarding domestic violence. It criminalizes several activities under the scope of DV that were not covered by the previous Code, including those that do not include physical violence but are nonetheless serious violations of the victim's human dignity. The present regulation sanctions four areas of domestic violence: emotional, physical, economic and sexual. The Criminal Code does not sanction verbal abuse. The major limitation of the present legal framework of DV as a crime is that the police are obliged to file a criminal complaint ex officio only if the offender committed an aggravated battery (Article 164 (3)), and DV involves serious physical injuries. In all other cases - if the DV involves less serious physical injuries or no physical injuries at all - it is upon the request of the victim to file a criminal complaint against the offender. 
The latest instruction of the Hungarian National Police Headquarters in relation to DV was passed in 2018 (Hungarian National Police Instruction (I. 25) No: 2/2018 on the implementation of police tasks relating to the handling of violence between relatives). It provides a very detailed protocol for the police on the necessary legal and administrative steps when taking measures and investigating in domestic violence cases. The most important tasks of the police defined in the instruction are the following: 1.) the instruction defines the necessary conditions and procedural steps of the different types of restraining orders; 2.) it regulates the ways of cooperation among the different FLR's, including the police, the court, the social services and other members of the Child Protection Perceiving and Reporting System and the role of the police in initiating cooperation; 3 .) it prescribes to provide sufficient information for the victims about their rights concerning filing a criminal complaint and about available victim-protection services; and 4.) it orders and specifies the regular education of the police staff who takes part in DV cases, including a mentoring system, conflict-management training and specific training about the legal and psychological aspects of domestic violence.

\section{Reporting rates about domestic violence}

We requested country-wide statistics about the number of the registered victims of violence against partners and family members (including the following crimes: domestic violence, sexual abuse, sexual violence, sexual exploitation, sexual coercion, coercion, deprivation of sys personal freedom, private justice, physical battery, homicide, aggravated cases of homicide). Altogether, there were 2334 victims registered in the above mentioned crimes where the offender was a partner or family member in 2017, and 1225 in the first half of the year 2018 (Coordination and Statistical Unit of the Ministry of Interior, 2019).

However, it is important to underline that solely domestic violence appears in the official DV statistics from the crime categories mentioned above. For comparison, there were only 339 cases of domestic violence as a crime registered in 2018, and 392 in 2019 (Coordination and Statistical Unit of the Ministry of Interior, 2020, as cited in Munk, (2020). These statistics show that the crime category of domestic violence makes up a small amount of all violent crimes committed against partners and family members. 
As a consequence of the COVID-19, we have seen a remarkable increase in the number of domestic violence crimes. According to the statistics, there were altogether 103 domestic violence crimes registered only in April and May of 2020, and the number of all registered domestic violence cases between 1 March and 31 August was 330 - which equals the number of cases in the whole year if compared to previous years (Coordination and Statistical Unit of the Ministry of Interior, 2020).

\section{The role of police, other front-line and first-responder agencies, and pertinent stakeholders in responding to high impact domestic violence}

Organizations in contact with victims of domestic violence and their most important tasks will be described in this chapter.

The police have a major role among the frontline responder organizations helping victims of domestic violence. Officers have to follow very detailed regulations regarding the handling of domestic violence as well as crime prevention duties that have been defined in different instructions and laws, already discussed in chapter 1. Among other tasks, they are authorized to issue temporary preventive (72 hours) restraining orders and to initiate preventive (long-term) restraining orders at the court. Reports can be made to the police through a telephone helpline or through the also free witness hotline, ensuring anonymity. If any violent action between family members is reported, police officers are sent to the venue without delay (as is required by the Hungarian National Police Instruction (I. 25) No: 2/2018 (ibid, Section 4). As mentioned earlier, the police are obliged to file a criminal complaint ex officio only if the DV involves serious physical injuries. In all other cases, the police only take measures and investigate if the victim files a criminal complaint.

The Child Protection Perceiving and Reporting System is an institutional network and protocol established to handle family situations of harm and neglect that concern children. It is divided into institutions providing services or performing authority tasks by the Act XXXI of 1997 on the protection of children and administration of guardianship. 
Authority tasks concerning children shall be performed by the guardianship office. Under the relevant legislation (Government Decree No: 149/1997. (IX. 10.) on guardianship offices and child protection and guardianship) the abuse or severe negligence of children or in case of any other severe cause of endangerment the guardianship office shall immediately take measures required for the protection of the child. The guardianship office may take the following measures to protect children: taking them into protective custody, providing temporary accommodations, temporary foster care, and permanent foster care.

Upon the victim's request, the guardianship office shall provide legal, medical, psychological and mental health assistance. In the scope, the victim and the offender shall be informed about potential therapy and other available help and conflict management opportunities. The guardianship office may order mediation proceedings ex officio or upon the request of the involved persons. The mediator shall notify the guardianship office without delay if urgent measures are required in a child's interest, particularly if the child's abuse or gross negligence is suspected by any parent (Government Decree No: 149/1997., ibid, Article 30/C).

The act on restraining order prescribes that if children are endangered by violence, the police and other frontline organisations have to report the threat to the Guardianship Office.

It is worth noting here that the children's rights representative shall (inter alia) advocate for and protect children's rights in child protection care (Act XXXI of 1997 on the protection of children and administration of guardianship, Article 11/A).

Service tasks are fulfilled by family support and child welfare services. According to the definition of the Act III of 1993 on social administration and social supports, the family support services provide support for persons and families needing help in crisis situations - including violence - to maintain their ability to manage their lives (ibid, Article 64 (1)). Child welfare services are special personal social services protecting children's interests using the methods and means of social work (ibid, Article 39 (1)). The primary task of child welfare services is to prevent and stop the endangerment of children. For this objective, the child welfare services operate, organize, and harmonize the Child Protection Perceiving and Reporting System regulated by Act XXXI of 1997 on the protection of children and administration of guardianship. The organizations named in the Act shall report - among other information - any incident or suspicion of domestic violence to the child welfare services in order to 
prevent and stop the endangerment of the child. Recording reports, exploring the problems of endangered children and searching for solutions are obligations of the child welfare services.

The operation of temporary homes for children, crisis centres, secret shelter homes and halfway houses is regulated by the Act XXXI of 1997 on the protection of children and administration of guardianship. Those children can be placed in a temporary home for children living in their family but were temporarily left without care and supervision or would be left without these in the event of a lack of intervention and whose care is endangered due to family difficulties. People in crises due to domestic violence can be accommodated in crisis centres and secret shelter homes. Secret shelter homes also help manage psychological injuries of abuse and give legal advice to protect the interests of the victim. The crisis centre may provide halfway-house services for the abused family leaving the shelter home as a supplementary service to help the victims' social reintegration.

Under Act CXXXV of 2005 on helping the victims of criminal offences and mitigation of damages by the government, victims can turn to any victim support service as well. The service can provide support by facilitating the enforcement of interests, protection of witnesses, financial support and mitigation of damages, as well as providing protected accommodations.

Victims of domestic violence often contact the health care services first, typically for the treatment of their injuries or in order to provide medical reports. If children are concerned with domestic violence, health care workers are obliged to report to child protection services, the guardianship office, and the police (based on whose report temporary preventive restraining may be ordered). Public education institutions also have a similar reporting obligation.

There are several NGO's that operate crisis management and psychological telephone helplines. Among them, the Blue Line (Kékvonal), operated by the Child Crisis Foundation (Gyermekkrízis Alapítvány), must be mentioned. Child abuse and lost children can be reported on a free telephone number. National Crisis Telephone Information Service (OKIT) aims to help victims of domestic violence and human trafficking on a phone number available free of charge, year-round throughout the country. According to Government Decree No: 1351/2013. on the national strategy between 2013 and 2016 on the fight against human trafficking and Government 
Decree No: 354/2012. (XII. 13.) on the identification order of victims of trafficking in human beings, placement to protected accommodation and cooperation among the institutional network of protected accommodations and other FLR's shall be coordinated by OKIT.

Although specific organizations are not named in the legal regulations, several NGOs work in protecting and supporting the victims of domestic violence.

\section{Good practice of co-operation between police, other front-line responder agencies, and pertinent stakeholders}

This chapter presents the work of the National Crisis Telephone Information Service (Országos Kríziskezelő és Információs Telefonszolgálat, hereinafter: OKIT). The organisation helps victims of domestic violence and human trafficking through a telephone line available free of charge, year-round throughout the country. Trained domestic violence counsellors (working in pairs) provide primarily counselling and information about available victim support services. In addition, they refer victims leaving their homes and escaping their abusers to one of the shelters or crisis centres operated by the state and by NGO's. A risk assessment tool supports the counsellors in assessing crisis situations and making decisions about the adequate response. However, the professional staff at OKIT reacts even if the evidence is not available; victims do not have to prove (by a medical report, testimony of witnesses or video footage) that abuse has occurred. All in all, the organisation can offer a low-threshold service targeted to the complex needs of DV victims and thereby decrease latency.

OKIT was launched in 2005, based on the findings and experiences of a pilot program related to a hotline focusing on domestic violence. Since 2005 the network of the institutions providing safe accommodation for victims and working in close cooperation with OKIT has been continuously developing (16 crisis centres, 2 secret shelters, 2 temporary homes were established just between 2007 and 2016). As a result, OKIT was able receive altogether 77,213 calls (not including an extra 67,212 fake calls) between 2008 and 2016 (Arnold, Hera, Meszaros \& Szabo, 2017, p. 6273). 
Among the strengths of the organisation, effective victim protection should be highlighted. There is a strict regulation about the confidentiality of shelter locations; OKIT also keeps their addresses confidential. Therefore, even victims escaping abusive relationships are not informed about their destination and, as a result, victims living in shelters feel safe. There are other policies that also increase trust: referrals are made to shelters, for instance, even if victims do not report DV incidents to the police and the organisation does not record calls. Victim protection is an important requirement even if the police contact OKIT because of a woman/family reported to be missing. The organization informs the police if the missing person was relocated by OKIT; however, the exact address of the victim's new location is considered as confidential information and is not sent to the police.

OKIT works in close cooperation with several organisations and institutions. In the event of an emergency call, counsellors at OKIT are responsible for primary crisis assessment and intervention. As information about the free capacity of shelters all around Hungary is available for the staff, they know at which institution the victims can be accommodated. In addition, OKIT works with the police; in the event of an emergency call, staff can report the incident to the police in order to ensure effective protection for the victims of violence between family members against threats and revenge. There is also close cooperation between OKIT and the Family Support and Child Welfare Services 1) before and during victims' flight from their abusers (in order to prepare and successfully implement the escape), 2) during victims' stay at shelters (in order to inform the Services about the developments that are achieved), and 3) before the victims leave the safe accommodations (in order to support their social reintegration). In addition, OKIT serves as a link between schools that are attended by child victims before and during their accommodation in shelters.

The organisation successfully facilitates the cooperation between governmental and non-governmental organizations. The website of the National Crisis Telephone Information Service states: "OKIT considers it important to cooperate with all of the actors that can and would like to take part in solving diverse problems, preventing crisis situations and conflicts" (bantalmazas.hu, 2020) to give collective, complex and operative responses to DV cases. 
A further way in which OKIT strengthens cooperation among professionals is that it regularly provides professional exchanges among the shelters - which take place either in forms of institution visits or workshops for experience exchange. Those are considered to be the most useful opportunities by the shelter workers to learn from field experiences and acquire good practices.

All in all, we consider the work of OKIT as an example of best practice, as the organisation is able to offer a low-threshold service that is available even for those victims who do not report DV incidents to the police, as they are afraid of the consequences and/or if the evidence does not confirm their testimony. The organisation can implement real victim protection by keeping information about the shelters and victims confidential and successfully coordinate the relocation of victims to institutions providing safe accommodation. Protecting victims is a core value, which is successfully achieved even by the network that is coordinated by OKIT. Mutual trust among the members of the network has successfully developed; the professional work of OKIT is known and respected by its partner organizations, primarily due to the high professional standards that are created by OKIT to guide professional practices, to be included in the training programs and methodological handbooks created by OKIT. Cooperation is supported even by effective information sharing. As a result, victims reaching out for help and calling the OKIT receive an adequate, professional and immediate response in the form of information, counselling and/or referral to institutions providing safe accommodation.

\section{Main challenges and issues to be anticipated}

A number of our interviewees pointed out shortcomings with respect to the training of professionals facing HIDV. Leaders of the social services and heads of police departments are usually well trained in recognizing and handling DV. However, police officers patrolling the streets (especially young officers without relevant experience) may not be prepared well enough to identify and address DV. Although, law enforcement education both at the secondary and tertiary level provides some training on DV, it is dominated by theoretical knowledge, which does not cover sensitization and is difficult to use in daily practice. The training of healthcare professionals hardly touches upon the subject of domestic violence. Compared to police and health care, professionals working in the social sector gain more 
knowledge about domestic violence as part of their college education, but they also lack specialised training that would offer practical knowledge. As a consequence of the absence of appropriate training, those professionals who directly or indirectly come into contact with violence often fail to recognise signs of DV. In addition, some of them easily get to the mistake of blaming the victims of DV. They are not aware of the mechanism and effects of DV and do not understand why victims do not call for help and leave their abusive relationships.

Those who work with affected families have identified severe structural and organizational problems in the social and healthcare sectors. The most striking ones were the intense fluctuation, burnout, the absence of young professionals, as well as the inefficient and overwhelming administrative and documentation tasks that hinder professional work. As a result, there is less time and energy for professional work, which negatively affects the support provided for the victims and professional development in the workplace.

As part of the study we interviewed crisis centres and secret shelters that offer temporary housing and social and psychological care for victims escaping relationship violence. A number of our interviewees stated that the physical protection provided for victims and staff members at the above institutions is insufficient, and complained that the legal instruments of the temporary preventive restraining order and preventive restraining order are not used effectively by the police and by the court, and do not provide adequate protection for the victim.

Experts of the social sector identified "migrating families" as the most serious midterm problem, which means that many families have moved among the system's various institutions for years. One reason for that is institutional dependency and the lack of support for victims after leaving the institutional net. Housing and integration to the labour market is especially difficult for former victims of domestic violence, especially if they raise their children alone. It is almost impossible to start an independent life after leaving crisis care. Supported housing works as a pilot and provided in small scale only.

One of the study's main conclusions is that prevention and rapid response require cooperation and information sharing between various actors - the police, family services, crisis care institutions and other institutions that come in contact with families, such as nursing services, kindergartens and schools. In our experience, 
personal and direct communication can greatly contribute to the effectiveness of collaboration, thus counteracting the impersonality and sometimes slowness of (mostly paper-based) bureaucratic processes.

Although cooperation is prescribed in protocols, it is rather rare in practice. Experts in most locations reported negative experiences concerning the absence of crosssectorial cooperation, its ad hoc character and the absence of information flow. There is no cross-sectorial or national informational database that would document and preserve information about DV incidents. Each frontline responder (police department, social service, guardianship office, shelter, etc.) from each sector has its own records that is typically not transparent to other frontline responders at different locations or different sectors. FLRs from various sectors cannot see the DV history of their clients. A national database and system of information that records relevant data about victims, offenders and DV incidents (e.g. testimonies from the parties, injuries, observations of the scene, measures, criminal procedures, etc.) would greatly support cooperation, prevention and risk assessment.

It is also important to note that we had the chance to interview many dedicated, highly qualified professionals during the study. These people often complement institutional solutions, seek their own paths, innovate, collaborate, and actively seek out training opportunities. According to the information we gained through our fieldwork, non-profit organizations bring innovative approaches, knowledge, experiences and trainings to the field, which are not sufficiently acknowledged and embedded into the system in general.

A key element of effective action against domestic violence is risk assessment. A further structural problem characterizing the police and the social and health care sectors in Hungary is the lack of sufficient, unified risk assessment tools and policies and measures as reactions to certain risks. Practices vary on a large scale throughout the country depending on the individual competencies and attitudes of the responding services, which intensify the latency of cases and hinder effective frontline response.

Due to the insufficient legislative frameworks, actual criminal charges in domestic violence cases take place very rarely. The reason for that is that according to the present legislation the victim has to file a complaint, provide and maintain a testimony throughout the criminal procedure, as well as provide several evidence 
regarding the regularity of violence as well as of the physical injuries supported by a medical report and by witness testimonies. The collection of sufficient evidence is very difficult. Due to fear, dependency, and the dynamics of violence, victims are usually reluctant to file a complaint against the offender or are likely to withdraw their complaints in the investigation phase. For the same reason, it is also problematic to provide witness testimonies. The long and bureaucratic nature of the investigation process discourages the victims further. A typical scenario is that the police initiate and conduct an investigation, and the prosecutor does not file charges. This practice is confirmed by the statistics from the police department in one of our case locations: there were altogether four DV crime cases investigated in 2018, three of them were based on a police report, and one of them was based on a citizen's report. None of them resulted in a criminal charge by the prosecution. Evidence in DV cases is evaluated freely by the prosecution. There are no unified, country-wide rules for the evaluation of evidence. That which would be enough for a charge in one county would not be enough in another. Stricter legislation and unified practices concerning reporting, risk assessment and management as well as the evaluation of criminal evidence would be the main conditions to support effective institutional responses to HIDV.

\section{References}

Act III of 1993 on social administration and social supports. (1993). https://net.jogtar.hu/jogszabaly?docid=99300003.tv

Act XXXI of 1997 on the protection of children and administration of guardianship. (1997). https:// net.jogtar.hu/jogszabaly?docid=99700031.tv

Act CXXXV of 2005 on helping the victims of criminal offences and mitigation of damages by the government. (2005). https://net.jogtar.hu/jogszabaly?docid=a0500135.tv

Act LXXII of 2009 on restraining orders. (2009). https:// net.jogtar.hu/jogszabaly?docid=a0900072.tv

Act $\mathrm{C}$ of 2012 on the Criminal Code. (2012). https:// net.jogtar.hu/jogszabaly?docid=a1200100.tv Arnold, P. and Hera, G. and Meszaros, Z. and Szabo, A. (2017). A „Kriziskeezelo" szolgálatok fejlesztése” elnevezésü, EFOP1.2.4-VEKOP-16-2016-00001 azonositó sqámú projekt keretében megvalósuló kutatás eredményeiroll (Findings of the research program that is implemented within the framework. of the "Development of crisis management services" program. https://www.kapcsoljegybol.hu/files/shares/PDF\%20dokumentumok/EFOP124_ZAROT ANULMANY_20180119.pdf\#page=72\&zoom $=100,0,134$

Coordination and Statistical Unit of the Ministry of Interior. (2019). Egyes személy elleni eröszakos büncselekemények ismerté vált természetes személyü sértettek száma az elkövetó sértetett kapcsolata szerinti bontásban. Budapest: Coordination and Statistical Unit of the Ministry of Interior.

Coordination and Statistical Unit of the Ministry of Interior. (2020). Büncselekmények. Budapest: Coordination and Statistical Unit of the Ministry of Interior.

Government Decree No: 149/1997. (IX. 10.) on guardianship offices and child protection and guardianship. (1997). https:// net.jogtar.hu/jogszabaly?docid=99700149.kor 
Government Decree No: 354/2012. (XII. 13.) on the order of identifying victims of human trafficking. (2012). https:// net.jogtar.hu/jogszabaly?docid=a1200354.kor

Government Decree No: 1351/2013. on the national strategy between 2013 and 2016 on the fight against human trafficking. (2013). http://www.kozlonyok.hu/nkonline/MKPDF/hiteles/MK13100.pdf

Hungarian National Police Instruction (III. 27) No: 13/2003 on the tasks of the police force related to domestic violence and the defence of minors. (2003).

Hungarian National Police Instruction (OT 26.) No: 32/2007 on the execution of police tasks related to handling violence between family members and the protection of minors. (2007). http://www.police.hu/sites/default/files/32_2007.pdf

Hungarian National Police Instruction (I. 25) No. 2/2018 on the implementation of police tasks relating to the handling of violence between relatives. (2018). https:// net.jogtar.hu/jogszabaly?docid=A18U0002.ORF\&txtreferer=00000001.txt

Munk, V. (2020). Mit ér a törvény, ha sokadszorra ver meg a párod? https://index.hu/belfold/2020/02/13/hiaba_van_ra_torveny_alig_ismerik_fel_a_hatosagok _a_csaladon_beluli_eroszakot/

Parliamentary Decree No: 115/2003 (X.28.) on the National Strategy for Social Crime Prevention. (2003). https://mkogy.jogtar.hu/jogszabaly?docid=a03h0115.OGY 